\title{
Language ability and entrepreneurship education: Necessary skills for Europe's start-ups?
}

\author{
Leanne Johnstone ${ }^{1,2}$ (D) Mariana Pio Monteiro ${ }^{3,4}$. \\ Inês Ferreira $^{3}$ • Johanna Westerlund ${ }^{2,5}$. \\ Roosa Aalto ${ }^{6}$. Jenni Marttinen ${ }^{6}$
}

\begin{abstract}
Language ability and entrepreneurial education are seen as essential resources for start-ups operating in intensified landscapes of internationalisation and globalisation. Deemed as the necessary skills for corporate effectiveness vis-à-vis rivals, this paper responds to calls for increased understandings of cultural components as vital to entrepreneurship and the product of institutional forces. Thus, it explores (a) the impact language ability has on start-up expansion; (b) the perceptions of international relations as based on language ability as a tool for cross-cultural communication; and (c) the role of educational context from the entrepreneurs' perspective. Based on interviews from European online start-ups across three discrete contexts-Finland, Portugal and Sweden - it concludes that contextual trends regarding language and education are founded upon the cultural-cognitive and normative pillars of institutionalisation. Further, by combining actor-context perspectives, it poses that language ability and education are resources borne from the domestic environment which positively moderate the start-up's international success. Nevertheless, the notion of learnt entrepreneurship remains contested. Taken together, this study contributes by offering deeper insight into the role of context on entrepreneurial tendencies by combining resource and institutional perspectives.
\end{abstract}

Leanne Johnstone

leanne.johnstone@oru.se

1 School of Business, Örebro University, Örebro, Sweden

2 School of Business, Society and Engineering, Department, Mälardalen Högskola, Västerås, Sweden

3 Escola Superior de Educação de Coimbra, Coimbra, Portugal

4 Católica Porto Business School, 4169-005 Porto, Portugal

5 Uppsala University, 75236 Uppsala, Sweden

6 Department of Business Management, Mikkeli University of Applied Sciences, Mikkeli, Finland 
Second abstract-Spanish La competencia y habilidad lingüística se están convirtiendo en requisitos indispensables para las nuevas empresas que operan en entornos de creciente demanda de internacionalización y globalización. Consideradas como necesarias para asegurar el éxito inicial y ventaja competitiva, este manuscrito se centra en el entendimiento de la conciencia cultural, la capacidad lingüística y la educación como pilares básicos para la iniciativa empresarial. Los objetivos son: a) explorar el impacto de la competencia lingüística en los planes de expansión inicial y futuros; b) investigar la percepción de las relaciones internacionales basadas en la capacidad lingüística como herramienta de comunicación intercultural; y c) definir el rol del entorno en la adquisición de habilidades lingüísticas y comunicativas desde la perspectiva del emprendedor. Basado en entrevistas a nueve nuevas firmas tecnológicas ubicadas en Finlandia, Portugal y Suecia, el estudio muestra diferentes tendencias sobre el rol de las habilidades lingüísticas y culturales como fuente de ventaja competitiva. Sin embargo, la idea de iniciativa empresarial como algo que se puede aprender o enseñar continua bajo debate, destacando la necesidad de futuros estudios sobre la importancia de la educación empresarial como entorno-dependiente.

Keywords Competitive advantage $\cdot$ Entrepreneurship education $\cdot$ Entrepreneurial orientation $\cdot$ Institutional theory $\cdot$ Language ability $\cdot$ Start-ups

Palabras clave competencia lingüística $\cdot$ educación empresarial · nuevas empresas · teoría institucional $\cdot$ ventaja competitiva

\section{Summary Highlights}

Contributions: This study contributes to international entrepreneurship literature by increasing understandings of the role of education and language (the measureable components of culture) for start-up (continued) success. It also contributes by integrating institutional and resource-based views, as well as has value for educators and entrepreneurs by gaining insight from international entrepreneurs.

Purpose/research questions: The paper aims to explore (a) the impact language ability has on start-up effectiveness; (b) the perceptions of international relations as based on language ability as a tool for cross-cultural communication; and (c) the role of context in the production of competent language and communication skills from the entrepreneurs' perspective. It seeks to analyse if cultural clusters exhibit similar trends in responses.

Findings/results: The study concludes the importance of language ability for start-up success to reduce the liability of foreignness. However, the role of entrepreneurship education appears contested as entrepreneurial orientation is predominantly intrinsic and entrepreneurship appears a culture in itself, irrespective of geography.

Limitations: Due to the limited number of interviews, the results are non-generalisable. Future studies can improve on this, as well as extend the questions to incorporate a specific focus on how language is used as a resource by international entrepreneurs. 
Theoretical implications and recommendations: The study suggests that the literature regarding the role of entrepreneurship education is in need of further investigation from the perspective of the entrepreneur. It also offers empirical evidence of integrating institutional and resource-based views.

Practical implications and recommendations: This study is practical in that it offers an overview for practitioners regarding the entrepreneurial culture in discrete contexts. Further, it highlights first-hand experiences from the entrepreneurs' perspectives. Future studies could advance on this by following a longitudinal perspective to assess if opinions change over time.

\section{Introduction}

Language ability and proficiency can be considered essential cultural resources for firms operating in landscapes dominated by intensifying internationalisation and globalisation to enable a strategic competitive advantage (Ernst and Young 2015; Hurmerinta et al. 2015; Isenberg 2008). Particularly, increased exposure to different markets necessitates cultural sensitivity (Etemad 2015) where understanding the benefits of resource tools such as language and education becomes vital (e.g. Holt 2008). Nowhere are these skills more paramount than for online 'born-globals' (see Bell et al. 2004; Isenberg 2008; Knight and Liesch 2016) as they are seen as the means to boost initial competitive edge vis-à-vis rivals and reduce liabilities of foreignness (Qian et al. 2013; Zaheer 1995; Zaheer and Mosakowski 1997). Hence, a better understanding of the cultural concepts and ideologies relating to language capability and entrepreneurial education is necessary for both professional and academic practitioners (see Andersen and Rasmussen 2004; Brannen et al. 2014; Engelen Heinemann and Brettel 2009; Fredriksson Barner-Rasmussen and Piekkari 2006; Kulkarni 2015; Roy Sekhar and Vyas 2016; Swift and Wallace 2011).

Due to the paucity of studies that address entrepreneurial orientation, knowledge and learning (Brush Manolova and Edelman 2008) as connected topics of interest, this paper explores the roles of language and education, the measureable components of culture, from the entrepreneurs' point of view. Few studies have analysed the influence of education and language on entrepreneurial behaviour (Díez-Martín Blanco-González and Prado-Román 2016; Hechavarría 2015; Segal Borgia and Schoenfeld 2005) beyond single contexts (e.g. Swift and Wallace 2011; Fredriksson Barner-Rasmussen and Piekkari 2006) and constructs ${ }^{1}$ (see Barner-Rasmussen et al. 2014). Further, more research is required beyond the multinational firm (Chiang and Yang, 2014). Thus, this study builds upon both micro (individual/organisational) and macro (national) levels of entrepreneurship (Harzing and Pudelko 2013) in three European contexts (Finland, Portugal and Sweden). It responds to calls for studies on the configuration of core values based on geography (da Rocha et al. 2017) by addressing if multilingual start-up companies achieve more international success than bilingual or monolingual ones from the perspective of the

\footnotetext{
1 That is, many studies explore language (e.g. Kulkarni 2015; Brannen et al. 2014; Harzing and Pudelko 2013; Fane 2012; Bergmann 2011; Leslie and Russell 2006; MacLean 2006; Andersen and Rasmussen 2004), education/learning (e.g. Farny et al. 2016; De Noni and Apa 2015; Laperrière and Spence 2015; Hytti and O'Gorman 2004; Krueger and Brazeal 1994; Donckels 1991) or culture (e.g. Überbacher Jacobs and Cornelissen 2015; Chiang and Yang 2014).
} 
entrepreneur. Moreover, it moves away from conventional studies based on firm-level financial performance outcomes (Brush Manolova and Edelman 2008) by assessing the non-financial outcomes of trust, organisational rapport and legitimacy, as well as whether institutionalised entrepreneurship education can increase firm performance on the global stage. Particularly, the paper explores: (a) the impact language ability has on start-up expansion and future expansion plans; (b) the perceptions of international relations as based on language ability as a tool for cross-cultural communication; and (c) the role of context in the production of competent language, communication skills and entrepreneurship orientation. It is founded on the assumption that formal institutional learning, coupled with informal institutional norms and values pertaining to language and culture, acts as internationalisation resources (see De Noni and Apa 2015). Therefore, by drawing on institutional and resource-based views, the paper builds upon the cultural constructs of language and education as necessary for global start-up success.

This study finds that language ability is a vital resource for start-up success and continued profit maximisation beyond solely economic terms. Although, it remains unclear if entrepreneurial education is necessary for boosting entrepreneurial orientation. Further, the paper contributes to both theory and practice. First, it contributes to the growing body of literature regarding international entrepreneurship where the focus is on language ability as a perceived competitive advantage, and how this is manifested over spatial levels as interpreted by the entrepreneurs themselves. Second, it answers to calls for the greater integration of entrepreneur research and institutional theory (Covin and Miller 2014; Tolbert et al. 2011), but more specifically the integration of institutional and resource-based views (Meyer et al. 2009; Peng et al. 2009). Third, it combines agent and context-centric perspectives (see Garud Gehman and Giuliani 2014), that is, the micro and the macro-level factors which 'make' the entrepreneur, thus offering a more nuanced understanding. Fourth, it is valuable for educators and potential entrepreneurs who may be thinking of entering global markets to gain insight from practice.

The paper begins with a literature review outlining the key concepts and theories for exploration. Thereafter, the method is communicated. Next, the findings and analyses are presented. Lastly, a concluding discussion is offered.

\section{Literature review}

Within international entrepreneurship research, the liability of foreignness (see Hymer 1976) assumes that the costs of entering a foreign market, such as those associated with 'the firm's unfamiliarity with the local culture' (Zaheer and Mosakowski 1997, p. 440), make it difficult for companies to achieve a comparative advantage vis-à-vis domestic firms. Thus, from a resource-based view (see Barney 1991), entering firms are assumed to be at an inherent disadvantage because they lack essential resources to compete on an equal par. Nevertheless, the rise of born-globals in an increasingly digitalised marketplace complicates such a view. That is, the liability of foreignness may be less pronounced for online businesses with competent language and communication skills as resources borne from domestic institutional environments, which are subsequently used in various foreign markets.

The cultural skills of language and - specifically learnt - entrepreneurial orientation (EO), drawn from both formal and informal domestic institutions, can be seen as 
practical resources for international entrepreneurship as the borders of time and space diminish. In this sense, institutional and resource-based views become integrated (see Meyer et al. 2009). Here, language is learnt within a discrete institutional environment before it translates into a resource, and the propensity of EO is arguably the result of both personal attributes as well as formal entrepreneurial education in discrete contexts, placing the individual as a 'resource' per se. Specifically, EO refers to the propensity of an individual to be entrepreneurial (Miller 2011) based on behavioural features such as innovativeness, risk-taking propensity and pro-activeness, among others (see Lumpkin and Dess 1996); features which arguably relate to culture as well as extend into the international arena (see Covin and Miller 2014).

The House et al. (2004) GLOBE project on culture and leadership furthers discussion on individual EO by proposing that certain countries are more likely to exhibit risktaking behaviours than others. This infers that EO is a product of the domestic environment, and is widely supported (see Dennehy 2015; Dorfman Javidan and Hanges 2012; Gupta Hanges and Dorfman 2002). It also bridges micro (individual) and macro (regional) perspectives. The House et al. study moves beyond individual country analyses to incorporate the idea of cultural clusters where certain cultures are more prone to corporate risk-taking as the result of institutional norms as well as domestic regulatory environments. Yet, cultural similarity is measured by the 'proximity' of clusters which are not necessarily geographically linked but bonded by shared linguistic groups or histories. These clustered magnetisms also assume that particular value systems are more likely to exhibit leadership tendencies than others, whereby 'culturally contingent characteristics' (Hoppe 2007, p. 4), such as ambition and risk-taking level, can be directly related to entrepreneurial intent within geographical borders and the willingness to cross these boundaries (see Mainela Puhakka and Servais 2015). Nevertheless, although 'culturally' similar, linguistic backgrounds (Okrent 2014) and education systems differ across nations which may, in turn, affect EO.

Individual entrepreneurs are increasingly required to be 'skilled cultural operatives' (e.g. Lounsbury and Glynn 2001, 559). Interactions between the individual, company and market stimulate learning and relationship-building and are essentially based upon communication, diversity and multi-layered networks (Larson and Starr 1993). Both entrepreneurial micro-level characteristics and macro-level contextual opportunities such as education and language assimilation effectively 'make' the entrepreneur (see Drakopoulou Dodd and Hynes 2012). Although, in contrast to the prevailing view in the liability of foreignness literature, the 'making' of newer digitalised firms that are born-global is most likely in the domestic context given that business is often conducted online. This is the result of a constellation of competencies from primarily tacit knowledge and skills (McDougall Shane and Oviatt 1994) which are commonly part of - and borne from - the (firm and) entrepreneurs' local environment (Bonaventura and Caserta 2012; Drakopoulou Dodd and Hynes 2012). Thus, the very foundations of entrepreneurial activity are based upon cultural underpinnings. Here, language is a form of learnt, dynamic cultural expression (Ghauri and Cateora 2014, p. 74) embedded into formal and informal educational systems as institutions over time and space, aiding market entry strategies whether knowingly or not. Further still, taught entrepreneurship in the locale can inadvertently promote EO for groups of individuals in a particular society. Therefore, language and educational skills, as the measureable components of culture, become resources to the budding international entrepreneur, as much as they are products of institutions in discrete geographical contexts. 


\section{Entrepreneurship, institutions and resources}

Given that entrepreneurship is 'a context-dependent social process' (Low and Abrahamson 1997, p. 435), institutional theory poses a useful research frame. It is considered useful in helping to explain the 'forces that shape entrepreneurial success' (Bruton Ahlstrom and Li 2010, p. 421; Tolbert et al. 2011). It can help elaborate upon the contextual differences in language skills and (entrepreneurial) education in discrete contexts that result in unique resource constellations for the start-up. As such, institutional theory, specifically Scott's (2014) institutional pillars, can help usefully address the domestic characteristics that give rise to unique resource constellations, rather than act as a diffusion mechanism in the foreign market as proposed in liability of foreignness studies (e.g. Zaheer 1995).

Peng et al. (2009, p. 64) refer to institutions as the 'rules of the game'. Specifically, these rules can relate to the formal and informal established patterns in a given context that, from an economics' perspective, 'structure human interaction' (North 1991, p. 3). From a sociological perspective, institutions 'comprise regulative, normative, and cultural-cognitive elements that, together with associated activities and resources, provide stability and meaning to social life' (Scott 2014, p. 56). Particularly, the regulative pillar constrains and regulates behaviours through the establishment of institutional rules and laws, the normative pillar regards prescriptive and evaluative roles relating to values and expectations and the cultural-contingent pillar relates to forms of cognitive schema (ibid.). The economics and sociological perspectives are, however, not dichotomies, but merely ways of framing institutional theory from different academic fields. Moreover, Scott's institutional pillars are not mutually exclusive, but rather formative, giving rise to unique entrepreneurial configurations in a given environment.

Institutional theory has been growing within international entrepreneurial research in recent years (e.g. Pinho 2017; Lounsbury and Glynn 2001). Particularly, the new institutional sociological branch is here posed as useful as it deals with addressing the underlying contextual reasons into entrepreneurial practices and resource assimilation. That is, the reasons why some people adopt entrepreneurial practices and acquire language skills as cultural resources can be explained through the guise of institutional theory based on various situational regulative, normative and cultural-contingent effects present in the domestic context. It offers a way of understanding why organisations - or the entrepreneur-businesses unit - within a field appear similar, beyond conventional sector-bound explanations. Indeed, these fields can be country-level (i.e. Pinho 2017), offering insight into contextually bound studies. Thus, institutional settings in the domestic environment form the bases of entrepreneurship.

As the entrepreneur and start-up can be considered as two sides of the same coin with the firm, internalising the entrepreneur's core values, traditional resource-based views relate to institutionalism (see K Brouthers L Brouthers and Werner 2008). For example, organisational legitimacy can be seen as a resource to reduce the liability of foreignness as a product of culturally contingent norms and perspectives. This legitimacy is a result of the legitimate acceptance in the host country of the start-ups' inherent value. It can be boosted by organisational rapport as a product of dialogue, communication and information exchange - i.e. social skills - which facilitates the establishment of external relationships over time and space (Tolbert et al. 2011; Suchman 1995), therefore increasing trust. Hence, institutional theory offers explanatory value as a theoretical framework to guide 
studies beyond single national contexts (see Bruton Ahlstrom and Li 2010). It also adds to theories of internationalisation by suggesting that global success may be the product of 'localised' institutionalised norms from the field-level that affect entrepreneurs at the individual micro-levels, embodying the value systems of the start-up itself. Here, the individual and the organisation are essentially viewed as one; together the product of the discrete institutional environment and affecting the entrepreneurial resources.

\section{Language, education and entrepreneurship}

Language skills permit communication, dialogue and information exchange which affect trust, rapport and legitimacy in foreign markets. Such skills, therefore, can boost cultural alignment (see Scott 2014) over time and space by engaging stakeholders and customers. Thus, language ability functions as a core resource for born-globals to meet the needs of overseas markets. Yet, language ability does not exist in isolation. Rather, it exists in series with other complementary elements, which may-or may not-lead to a competitive advantage as a unique set of company resources (Maclean 2006). In this sense, language ability can promote performance outcomes beyond economic concerns as part of a wider resource package. However, language capability does not necessarily translate into cultural awareness and vice versa (Andersen and Rasmussen 2004; Barner-Rasmussen et al. 2014), and language or cultural understanding does not automatically equate good communication (Andersen and Rasmussen 2004). Thus, the role of education may offer some explanatory value alongside language ability as tools for fostering relationships abroad (Swift and Wallace 2011), as well as for start-up firms to penetrate deeper, and more rapidly, into global markets.

Social capital in the form of communication, dialogue and information exchange is intrinsically intertwined as a valuable personality skill that translates into entrepreneurial competitive advantage (Bonaventura and Caserta 2012; Chuang Chen and Lin 2016; Leslie and Russell 2006; McKeever Anderson and Jack 2014) by relating - and comparing - to the 'other' (Fligstein 1997). Transferrable over space, social skills are manifested in the individuals who act as representatives of the firm (see Chiang and Yang 2014; Davidsson and Honig 2003; Frank et al. 2007) through language in all its guises. Thus, globalisation thrives on international cross-cultural communicative relationships and leaders (House et al. 2004; Lawrence 2015). Nevertheless, communication style is spatially contingent and therefore has both mediating and moderating effects on firm performance, although language as an asset can be considered 'the single most important factor when we study how communication takes place between cultures' (Andersen and Rasmussen 2004, p. 231). As such, it is undisputable that the success of the start-up is reliant upon interactions with potential customers as stakeholders (Frank et al. 2007, 228) by building social ties and repeat custom (Pollack et al. 2016). Fundamentally, language has been proposed as the barrier, the facilitator and the power source of international business (Marschan-Piekkari D. Welsh and L. Welsh, 1999; Trinder 2013). It is the intangible, tacit asset of an entity and its actors, and as a component of communication, it is a measurable dimension of culture.

Language ability directly relates to education. Specifically, language production is the artefact of internal education systems whilst also concurrently allows the practice of education to occur. Therefore, language and education mutually reinforce one another. Whether public or private, self-directed or taught, these factors together strengthen 
entrepreneurial success likelihood. As humans, language ability is our primary tool to convey meaning, and it is fundamental when conducting business over international spatial and temporal levels. However, this is not to say that language ability guarantees cultural understanding or organisational success. For example, Überbacher et al. (2015) note that cultural awareness is a necessary skill to be learnt by entrepreneurs, although culture itself can never fully be learnt by those externally positioned. With regard to the internationalisation process of start-up firms, learning refers to the assimilation of ideas, i.e. being educated in language and/or entrepreneurship, which improves communication networks across time and space. This is necessary for successful market entry which can be 'measured' per se as start-up success.

Some argue that entrepreneurial behaviour, i.e. EO, is the product of entrepreneurship education (e.g. Autio et al. 1997; Bird 1988, 1992; Boyd and Vozikis 1994; Bowen and Hisrich 1986; Bates 1995; Erikson 2001; Gorman Hanlon and King 1997; Krueger and Brazeal 1994; Welsh Tullar and Nemati 2016), while others detect a weak connection, arguing that entrepreneurs are often less educated than the general population (e.g. Jacobowitz and Wilder 1982). Recently, there has been a growth of entrepreneurship education literature (e.g. Fayolle 2013; Farny et al. 2016; Urban 2006) that reasons education is critical to the development of attitudes, skills and positive perceptions of entrepreneurship (e.g. Bergmann 2011). Notwithstanding, several authors argue for more rigorous - and up-to-date - studies to help theorise the influence of education (Donckels 1991; Gorman Hanlon and King 1997; Krueger and Brazeal 1994) and-as we pose-language on culturally embedded entrepreneurial tendencies.

Ultimately, entrepreneurship can be considered a cultural movement reinforced through education (Drakopoulou Dodd and Hynes 2012; Rae 2012) and language ability (MacLean 2006) which are instrumental to start-up success. That is, much of the traditional internationalisation theories, such as the stage-based approach (Johanson and Vahlne 1990) or resource advantage theory (Hunt 2002), are not applicable for today's born-globals. These firms do not follow a gradual stage-by-stage pattern of internationalisation but exhibit high global market commitment soon after inception (McAuley 1999; Crick 2009). This is arguably due to domestic institutional forces that focus on continuous learning (see De Noni and Apa 2015; Etemad 2015) and social skills (see Fligstein 1997). To this end, the underlying educational and cultural systems which support and underpin the entrepreneurial mind set (Farny et al. 2016; Johannisson 2016) require more attention in the production of essential global resources relating to EO and language ability.

\section{Methodology}

Rather than focusing on discrete case studies as is common in entrepreneurial research, this paper is founded upon the micro-level entrepreneurial opinions, collated into discrete national responses which can be explored under the realm of institutional theory. Nine European start-ups within technologically based industries from the three discrete European linguistic contexts - Finland, Portugal and Sweden - are investigated to combine micro-level perspectives into aggregated national macro-level conclusions. This will add to the ontology of 'what is', as well as the epistemological explanatory factor of 'how' via an institutional perspective as a framing mechanism, aiding to studies on the 
role of culture as moderating network-building relations (e.g. Klyver and Foley 2012; Dodd and Patra 2002) and leading to start-up (continued) success.

The methodological approach followed several stages. First, several academic journals and books were consulted to inform the initial scope of this study. From this, broad themes - with regard to entrepreneurship, language and education-were outlined, stimulating the exploration of the aforementioned research parameters from the start-up companies' perspectives. An initial literature review was refined over time in order to develop the theoretical framing. Throughout this process, the concepts and problematisation were also refined in order to contribute to the international entrepreneurship research stream. ${ }^{2}$

Second, in order to obtain the perspectives of the entrepreneurs themselves regarding language and education as sources of competitive advantage, a qualitative methodology was adopted for the data-gathering stage. Particularly, semi-structured interviews constituted the main method. The study design involved question areas operationalised around themes relating to language ability, entrepreneurial education and international relations. Regarding the firms, technology-based online start-ups were selected in order to (a) allow a more justifiable comparison and (b) reflect the increasing importance of information communication technologies (ICTs) in the international marketplace (see Ernst and Young 2015). The criteria for selection were that the start-ups were bornglobal, based online, operated internationally and orientated towards private consumer markets. Thus, technological orientation was not deemed a 'linguistic advantage' per se, even though digitalisation and coding procedures could be considered by some as a communication means. ${ }^{3}$

Initial contact (telephone, email and face-to-face) was made with formal requests to participate. The companies were provided basic information regarding the nature of the study in order to stimulate interest. This canvassing period spanned 1 month before the interviews occurred, resulting in the participation of nine technologically based start-ups, three in each discrete context (Finland, Portugal and Sweden) during February and March of 2016. The semi-structured interviews ranged from 19 to $56 \mathrm{~min}$ and were piloted by three academics - one in each country - to ensure that they were applicable for the research purpose and any issues were ironed out. Two researchers were responsible for the country-specific organisation, recording, transcription and (back)translation of the start-up companies' interviews. Further, upon transcription, the interviewees were sent copies for respondent validation before analysis (Bryman and Bell 2015, 630; Hartley 2004). Inter-rater reliability checks were secured through online and personal meetings, founding the bases of the discussion whereby relevant concepts and themes were drawn from the transcribed material via an illustrative case design (Yin 2012). This served to guide the study and more general discussion along the research process. As the purpose of this research is to gain a deeper understanding of context on the success of internationally discrete start-up companies in relation to language and entrepreneurship education, the firms' names have been anonymised as it is not the particular firms themselves that are of interest to the research agenda. Nevertheless, Table 1 provides a summary of the start-ups' main business orientations, informing the empirical background.

\footnotetext{
${ }^{2}$ This also involved feedback from two anonymous reviewers who helped outline useful concepts for the study.

${ }^{3}$ This point was brought to our attention by an anonymous reviewer.
} 
Third, the analytical procedure involved a three-step process for data analysis. The first step attributed a priori literature codes regarding communication, informationsharing and knowledge as key components of language and education vital to entrepreneurial success. This allowed the interviews to be framed based on extant literature, serving as the baseline to establish emergent concepts and themes. The second step involved analysing the interview transcripts to make sense of the findings from the entrepreneurs' perspective. This involved tabularising and coding quotations to gain better insight into the ontological and epistemological viewpoints as related to context. The third step involved comparing, contrasting and grouping key concepts and interview themes from the literature base and analytical material. As some concepts were deemed to overlap, the thematic analyses aim to be as representative as possible, informing the

Table 1 Overview of start-up companies business and context scope

\begin{tabular}{|c|c|c|c|}
\hline $\begin{array}{l}\text { Company } \\
\text { and } \\
\text { context }\end{array}$ & Main business & Operations context & $\begin{array}{l}\text { Interviewees' } \\
\text { position }\end{array}$ \\
\hline $\begin{array}{l}\text { Company } \\
\text { A, } \\
\text { Finland }\end{array}$ & Designs web and mobile phone services & $\begin{array}{l}\text { Finland, Sweden and South Korea. } \\
\text { Currently entering Hong Kong }\end{array}$ & Co-founder \\
\hline $\begin{array}{l}\text { Company } \\
\text { B, } \\
\text { Finland }\end{array}$ & $\begin{array}{l}\text { Provides online services for personal } \\
\text { trainers and sports enthusiasts }\end{array}$ & Finland, the Netherlands and the USA & $\begin{array}{r}\text { Chairman of } \\
\text { the Board }\end{array}$ \\
\hline $\begin{array}{l}\text { Company } \\
\text { C, } \\
\text { Finland }\end{array}$ & $\begin{array}{l}\text { Provides online platforms for } \\
\text { international students regarding study } \\
\text { advice and practical information }\end{array}$ & Finland, yet hopes to expand & CEO \\
\hline $\begin{array}{l}\text { Company } \\
\text { D, } \\
\text { Portu- } \\
\text { gal }\end{array}$ & $\begin{array}{l}\text { Creates and increases treatment } \\
\text { opportunities with stem cells, } \\
\text { contributing to science evolution in } \\
\text { the cell therapy }\end{array}$ & Portugal, Spain and Italy & $\mathrm{CEO}$ \\
\hline $\begin{array}{l}\text { Company } \\
\text { E, } \\
\text { Portu- } \\
\text { gal }\end{array}$ & $\begin{array}{l}\text { Produces sensor information to measure } \\
\text { amounts of oil and gas in tanks }\end{array}$ & $\begin{array}{l}\text { Mainly the USA and Canada, but also } \\
\text { France, Spain, Portugal, Brazil, the } \\
\text { UK and Australia }\end{array}$ & CEO \\
\hline $\begin{array}{l}\text { Company } \\
\text { F, } \\
\text { Portu- } \\
\text { gal }\end{array}$ & $\begin{array}{l}\text { Provides internet systems in developing } \\
\text { countries }\end{array}$ & Latin America and Africa & $\begin{array}{l}\text { Product } \\
\text { Manager }\end{array}$ \\
\hline $\begin{array}{l}\text { Company } \\
\text { G, } \\
\text { Swe- } \\
\text { den }\end{array}$ & $\begin{array}{l}\text { Provides software and online solutions } \\
\text { for capturing world sporting events }\end{array}$ & $\begin{array}{l}\text { Operates in } 40+\text { countries on almost all } \\
\text { continents }\end{array}$ & CEO \\
\hline $\begin{array}{l}\text { Company } \\
\text { H, } \\
\text { Swe- } \\
\text { den }\end{array}$ & $\begin{array}{l}\text { Produces household security sensors } \\
\text { connected to clients' smartphones }\end{array}$ & $\begin{array}{l}\text { The Nordics (Norway, Sweden, } \\
\text { Denmark and the UK), Europe. } \\
\text { Plans to extend to the USA late } \\
2016\end{array}$ & Co-founder \\
\hline $\begin{array}{l}\text { Company } \\
\text { I, } \\
\text { Swe- } \\
\text { den }\end{array}$ & Provides free internet for smartphones & $\begin{array}{l}\text { Worldwide users, mainly Brazil, } \\
\text { Mexico, the USA and India }\end{array}$ & CEO \\
\hline
\end{tabular}

The contexts exist in the form as expressed in the interviews and are not standardised 
subsequent discussion by bonding both actor and context-centric perspectives. This allowed the inquiry to be opened up (see Bazeley 2013, p. 149; Strauss 1987, p. 29) for meaningful thematic analysis as well as explanatory value by adopting an institutional perspective and establishing propositions from the findings to inform future research.

\section{Data analysis}

\section{Olá, hei, hej!}

Olá, hei, hej! Three words, three letters, three countries, one meaning. Our discrete cases pose three distinct language groups-Finnish from the Finic-Uralic languagebranch, Swedish from the North Germanic European group and Portuguese from the Ibero-Romance European - which may yield differences in resource constellations relating to language and education.

For the majority of the start-ups, language appears to be source of competitive advantage, yet a spectrum exists from necessity to indifference. To this end, general level themes are drawn out from the assumption that multilingual start-up companies achieve more international success than bilingual or monolingual ones (Table 2).

Although demonstrating a colourful array of primarily European languages, most firms appear satisfied with their current language abilities and strategies as they are necessary for their current operating markets. Notwithstanding, the Finns and Portuguese indicate a willingness to develop these skills, thus improving their resource package.

The interviewees remain divided in the consideration of language as a competitive advantage. For example, the Portuguese unanimously agree that language 'is a huge advantage, especially when [...] talking about global markets' (Company D), although the Finns only generally agree - the exception being Company B that has a multinational team and already feels at an advantage. Meanwhile, two of the three Swedes remain conflicted stating: 'I don't see it as a competitive advantage. It is a must of doing business, that's it' (Company I) and '[It] depends on your ambition I would say' (Company G). This perhaps asserts that the Swedes take their language skills for granted in the internationalisation process and also infers an unwillingness to adopt long-term linguistic strategies for new market penetration. Nevertheless, all companies agree that without language skills, new international businesses would fail, to which Company F extends: 'above all start-ups like us'. Here, the Swedes somewhat contradict themselves by not assigning such ability to competitive advantage. Nevertheless, Company D (Portugal) outlines the role of context as a contributing factor which links the micro and macro perspectives, consistent with the company's domestic - rather than international-outlook. The Portuguese indicate that it is not always necessary for firms to need such advanced language skills as context can constrain action and inform effectiveness as the normalisation of language ability is contextually embedded. This illustrates the hampering potential of institutionalisation which can negatively affect internationalisation potential.

Contextualisation is also reflected in the shared language histories between Sweden and Anglo-Saxon countries with English as the business lingua franca. These linguistic histories, stemming from Germanic roots, are shared alongside the colonial histories of Viking exchange which increase assimilation potential. Effectively, the Swedish 
Table 2 Summary of start-up operating languages and strategic orientation

\begin{tabular}{|c|c|c|c|c|c|c|}
\hline & & $\begin{array}{l}\text { Primary } \\
\text { language(s) }\end{array}$ & $\begin{array}{l}\text { Secondary } \\
\text { language(s) }\end{array}$ & $\begin{array}{l}\text { Future } \\
\text { language(s) }\end{array}$ & $\begin{array}{l}\text { International } \\
\text { orientation }\end{array}$ & $\begin{array}{l}\text { Long-term } \\
\text { language strategy }\end{array}$ \\
\hline \multirow[t]{3}{*}{ Finland } & $\begin{array}{l}\text { Company } \\
\text { A }\end{array}$ & Finnish & English & - & Yes & No \\
\hline & $\begin{array}{l}\text { Company } \\
\text { B }\end{array}$ & English & $\begin{array}{l}\text { Finnish, } \\
\text { Swedish, } \\
\text { German }\end{array}$ & - & Yes & $\begin{array}{l}\text { Possibility of } \\
\text { incorporating } \\
\text { Portuguese }\end{array}$ \\
\hline & $\begin{array}{l}\text { Company } \\
\text { C }\end{array}$ & English/Finnish & $\begin{array}{l}\text { Spanish, French, } \\
\text { German and } \\
\text { Russian }\end{array}$ & - & $\begin{array}{l}\text { Yes and } \\
\text { domestic }\end{array}$ & No \\
\hline \multirow[t]{3}{*}{ Portugal } & $\begin{array}{l}\text { Company } \\
\text { D }\end{array}$ & Portuguese & $\begin{array}{c}\text { English, Spanish } \\
\text { and German }\end{array}$ & - & No & $\begin{array}{l}\text { Yes - to } \\
\text { standardise } \\
\text { everything to } \\
\text { English }\end{array}$ \\
\hline & $\begin{array}{l}\text { Company } \\
\text { E }\end{array}$ & Portuguese & $\begin{array}{l}\text { English and } \\
\text { French }\end{array}$ & $\begin{array}{l}\text { More } \\
\text { English } \\
\text { and } \\
\text { French }\end{array}$ & Yes & $\begin{array}{l}\text { No. But, would } \\
\text { like to develop } \\
\text { French }\end{array}$ \\
\hline & $\begin{array}{l}\text { Company } \\
\text { F }\end{array}$ & English & Portuguese & $\begin{array}{l}\text { More } \\
\quad \text { indige- } \\
\text { nous } \\
\text { lan- } \\
\text { guages }\end{array}$ & Yes & No \\
\hline \multirow[t]{3}{*}{ Sweden } & $\begin{array}{l}\text { Company } \\
\text { G }\end{array}$ & Swedish & English & - & Yes & No \\
\hline & $\begin{array}{l}\text { Company } \\
\mathrm{H}\end{array}$ & Swedish/English & - & $\begin{array}{l}\text { More } \\
\text { English }\end{array}$ & Yes & No \\
\hline & $\begin{array}{l}\text { Company } \\
\text { I }\end{array}$ & English & Swedish & - & Yes & No \\
\hline
\end{tabular}

respondents equated language ability and competitive advantage to a lesser degree than the other linguistic groups, although recognising it as vital for business survival which may be explained via normative and cultural-cognitive institutionalisation over time and space.

Although English is considered by all companies as the language of primary interest for international business, discrete trends are clear. The Finns note Russian and Mandarin of future importance, whereas the Portuguese pose BrazilianPortuguese and Mandarin, and the Swedes note Spanish. These trends indicate potential foreign market selection as the recursive process of strategising by assimilating core language skills deemed necessary to penetrate such (emerging) markets. They also are inferential of historical ties. Indeed, this may either be the result of prior ties in the broad sense of historical national acquaintances that stimulate legitimising effects and perceived trust or the perceived corporate effectiveness of future ties based on both financial and social concerns for emerging markets. That is, the choices may be a reflection of normative underlying context-bound assumptions on future markets which can relate to, for example, geography, history and sector. Taken together, language ability is evidently vital to future development and therefore can be seen 
as a source of competitive advantage from the entrepreneurs' perspective, affecting start-up success likelihood.

Multilingualism is considered essential for sound business practice by the Finns who state that 'if you don't have the language skills [...] you miss that important tool for creating contacts' (Company A). Further, 'when you do business, at least the final service has to be in the local language' (Company B). Thus, from initiation to end-service, language infiltrates the whole business process for the Finns. This 'essentialness' is also outlined by Company D of Portugal where 'attention to language skills [...] can have a positive impact [...] on the company's operations'. These findings relate to the assumption that language ability affects organisational rapport, trust and legitimacy. Further, the responses extend communication as relating to feedback processes, cooperation, international scope and quality. For example, Company E states that 'most [...] start-ups need to have an international scope', to which Company F furthers:

'Language and communication are the keys to achieve success. It is through language that we communicate our company and our products. And, if we don't communicate well through language we will fail. Our daily operations are conditioned by the quality of communications'.

This infers that inadequate communication is detrimental to business legitimacy. If communication is on a foundational level per se, it can compromise the corporate image of the start-up and effect business potential. From a Swedish perspective, language ability through multilingualism is considered to pose little problem, apart from more effort on the behalf of the Swedes. The insinuation of resentment with regard to communication with customers who have inferior English levels suggests a misalignment between country-level skills, which are the product of embedded institutionalisation, as instigating frustration and hindering positive relations: 'In Sweden, you can do business in English, but in Brazil [...] nobody speaks English so we have to hire people to speak Portuguese'; 'we only hire people with good English skills' (Company I). Companies $\mathrm{G}$ and $\mathrm{H}$ propose patience on behalf of the Swedes dealing with foreigners' lower English levels as illustrated by the quote from Company H:

'There are plenty of examples of companies [...] where English is not the natural second language and you can spot that immediately $[\ldots]$ you definitely lose credibility straight away so you have to appear as almost as English is your first language $[. .$.$] if you don't have that, you need to take help'.$

Of course, these are subjective opinions from a selection of entrepreneurs and not sweeping cultural generalisations. Nevertheless, such normativity exhibited by the Swedes offers institutionalisation to varying degrees whereby perceptions of the 'other' are framed by internal, contextually bound assumptions. This is reinforced via the use of modals verbs such as 'have to' and 'need to' which suppose the Swedish interviewees as the purveyors of mastered second languages, discrediting those 'inferior' by assuming what can be interpreted as an authoritative role. Indeed, this may relate to the strong internal education systems as regulatory forces in Sweden where languages are incorporated from an early stage as products of the domestic institutional education system, i.e. the regulative pillar of institutionalisation. Nevertheless, start-ups from other countries may perceive language assimilation and ability as extremely difficult, as their institutional environments focus on other skill sets or different language branches. 


\section{Rapport through similarity?}

All business is founded upon relationships whether internal or external, thus the extent to which the start-up communicates in its customers' lingua franca is likely to improve organisational trust and rapport, as well as build legitimacy in the eyes of the 'other'. Appendix 1 provides an extensive summary and some empirical examples of the more nuanced themes drawn out from the interviews with regard to communication aspects and cultural awareness between the start-ups and their customers. These primary themes are overviewed in Table 3 below. They are related to the concepts of trust (T), organisational rapport (OR) and legitimacy (L), which were drawn out from the literature review and provide a detailed thematic analysis at the national level (Fig. 1). ${ }^{4}$ And although many of these themes may overlap, they serve to highlight that the start-up companies' perceptions are varied per context. To this end, the illustrative examples provide an understanding based on rich description of the role of context in the interpretation of communicative rapport as related to smooth business processes.

For the Finns, relational aspects such as adaptation to the local culture are emphasised, as well as a generally positive attitude towards cultural difference. Notwithstanding, Company A also states it 'not necessary [to modify your behaviour] when working abroad [as] everybody can be themselves'. The Finns also stress the importance of ensuring that the correct message is received by the foreign counterpart and that bilateral cultural education and learning should be the foundation of building sustainable business relations. This is exemplified in the prevalence of a communicative approach based on organisational rapport. As such, core values such as transparency and openness, alongside respect and tolerance, are presented, moving beyond traditional neoclassical ways of doing business. In this sense, the Finns embrace the position that cultural awareness is a necessary skill to be learnt by the entrepreneurs.

The Portuguese, however, take a more pragmatic approach which is slightly orientated to legitimising effects and has managerialist intonations: ; 'I have never had serious problems of miscommunication [...] due to language difference. We just need to take care and be sure everything is okay and all was well understood' (Company E). Nevertheless, Company F aligns more so with the Finns regarding to the need to adapt and actively learn about the other culture. The Swedes emphasise legitimacy the most by adopting practical responses that infer corporate aims of strategic competitive advantage such as: 'We are going to need to adapt [...] because in many countries English is not as widely used' (Company H); 'You have to be careful that you don't just do things as you would at home and assume that people will do [as they say] (Company I). Here, legitimacy is outlined regarding the a priori of 'credibility' which suggests superiority in eloquent English-language skills can boost corporate image and therefore competitive advantage. Thus, one can view this as a spectrum from the proactive, rapport-building communicative Finns, to the more pragmatic legitimising Swedes who are instrumental when conducting business over national (online) borders; that is, adaptation and cultural tolerance as the 'by-products' of conducting international business.

The Finns and Portuguese unanimously agree that culture is a competitive advantage with Company C (Finland) noting such skills as the 'ground for all doings', that is, they are

\footnotetext{
${ }^{4}$ Note that these categorisations can also be negatively related, i.e. caution negatively correlates to trust, further some of the categories relate to more than one core concept.
} 
Table 3 The main themes regarding business-customer rapport-building

\begin{tabular}{|c|c|c|c|}
\hline Themes & Finland & Portugal & Sweden \\
\hline Caution $^{\mathrm{T}}$ & $\checkmark$ & & \\
\hline Closeness to customer ${ }^{\mathrm{OR}}$ & & & $\checkmark$ \\
\hline Communication/skills necessity ${ }^{\mathrm{OR}}$ & $\checkmark$ & $\checkmark$ & $\checkmark$ \\
\hline Bilateral cultural education $^{\mathrm{OR}}$ & $\checkmark$ & $\checkmark$ & \\
\hline Credibility $^{\mathrm{L}}$ & & & $\checkmark$ \\
\hline Cultural adaptation $^{\mathrm{L}}$ & & $\checkmark$ & \\
\hline Cultural difference $\mathrm{eR}^{\mathrm{OR}}$ & $\checkmark$ & & $\checkmark$ \\
\hline Cultural integration $^{\mathrm{T}}$ & & $\checkmark$ & \\
\hline \multicolumn{4}{|l|}{ Cultural interaction ${ }^{\mathrm{OR}}$} \\
\hline Cultural responsiveness $^{\mathrm{L}}$ & $\checkmark$ & $\checkmark$ & $\checkmark$ \\
\hline Cultural richness $^{\mathrm{OR}}$ & $\checkmark$ & & \\
\hline Cultural understanding/tolerance ${ }^{\mathrm{T}}$ & $\checkmark$ & $\checkmark$ & $\checkmark$ \\
\hline Empathy $^{\mathrm{T}}$ & & $\checkmark$ & $\checkmark$ \\
\hline Equality $^{\mathrm{L}}$ & & & $\checkmark$ \\
\hline International culture ${ }^{\mathrm{L}}$ & & & $\checkmark$ \\
\hline Local responsiveness/local representation ${ }^{\mathrm{L}}$ & & $\checkmark$ & $\checkmark$ \\
\hline Management as a role model $^{\mathrm{L}}$ & & $\checkmark$ & \\
\hline Open-mindedness ${ }^{\mathrm{OR}}$ & & $\checkmark$ & \\
\hline Respect $^{\mathrm{T}}$ & & & $\checkmark$ \\
\hline Team spirit $^{\mathrm{OR}}$ & $\checkmark$ & & \\
\hline Textual discourse $^{\mathrm{L}}$ & $\checkmark$ & & \\
\hline
\end{tabular}

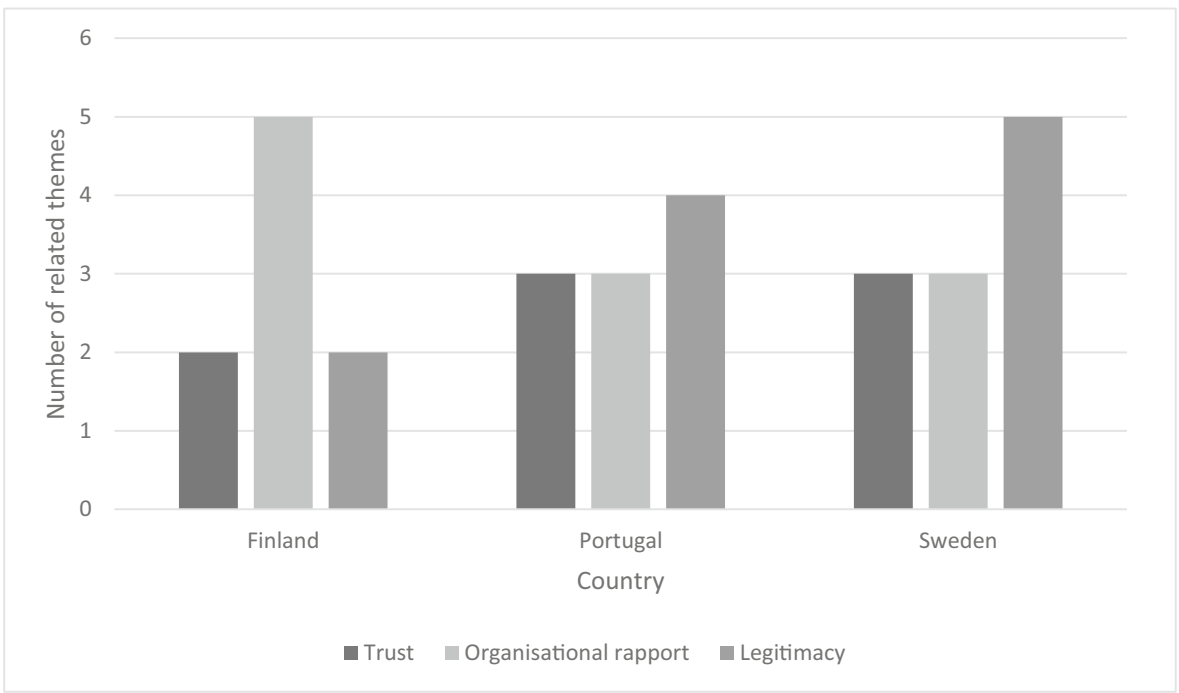

Fig. 1 Analytical comparison between literature-based core concepts and interviewee responses based on the thematic analysis 
essential in order to establish good relationships within the business world. Yet, the Swedes' responses vary and cultural significance appears dependent on multiple control factors such as location and sector (Company G). Further, Company H highlights that even though a company may not need cultural skills in the beginning, these become more important with regard to innovation over time, composing part of the organisation's internal resource systems and complementing the resource-based view of the firm. This suggests the incremental institutional assimilation of culture over time and (cyber)space that moves from the domestic realm to the foreign. It also echoes original uses of institutional theory in the liability of foreignness literature that supposes firms overcome the liability by integrating, mimicking or diffusing in the foreign market (see Zaheer 1997).

\section{An illustration of shared histories}

Given that Finland and Sweden occupy the House et al. (2004) Nordic cluster, the startup firms from these countries are arguably expected to exhibit similar trends. This similarity does not relate to language but rather is based on shared histories and proximity. Therefore, Finland and Sweden - in theory-should display comparable behaviours, opinions and trends, which would be dissimilar to Portugal in the Latin European cluster. Thus, detailed nuances from the entrepreneurs' responses offer further points of interest, especially as both the Swedish and Finnish interviewees overtly refer to one another without probing.

Company B (Finland) notes that when working with Swedes he tries to be as 'diplomatic as possible [by] trying to act in a way [he thinks] would [be] the most comfortable'. This accords with the notion that the Finns highly regard organisational rapport in order to make the 'other' feel comfortable and, in many respects, represents learning informal social skills and cues based on continuous improvement for an improved cultural resource base. Meanwhile, Company $\mathrm{H}$ of Sweden comments on prejudices he has about the Finns:

'... they are great to work with, but take some time getting used to as they are quiet. The northern part of Finland is not as good in English. A big difference in the profession, very different [than] if you are in the South'.

This 'quietness' is of interest, given that the Finns appear to actively concentrate on building a communicative approach. Also of interest is the regional divide between the north and the south, suggesting that 'national' culture is indeed not entirely national; a view that is addressed in Tödtling and Wanzenböck's (2003) study of regional patterns of entrepreneurship in Austria. One can only hazard a guess that these sources of - perhaps unfound-criticism (from both sides) are most probably the combined result of institutionalisation, that is, the result of shared - and sometimes conflicted-histories, as well as personal experience.

It is inevitable that comparisons are made between business-customer market bases based on commonly-held, institutionalised or even stereotypical views, which can be both positive and negative for a variety of reasons. For example, Company $\mathrm{G}$ of Sweden praises Finnish customers for their quick adaptation to new technologies and speed in signing contracts, comparing them to their much slower Swedish counterparts. Here, institutionalisation is orientated negatively towards the respondent's home market by the 
recognition that 'home' is not always the most efficient from a corporate perspective. Nevertheless, the fact that both countries offer illustrative examples of their neighbours suggests deep-seated connections and long-established business networks between Finland and Sweden, partially verifying of the notion of the House et al. (2004) cultural clusters.

\section{Manufacturing entrepreneurs}

Entrepreneurship does not appear to be an institutional movement given that the responses of our interviewees focus on the individual-level. To this end, the patterns do not support the view that underlying educational and cultural systems are necessary prerequisites to become an entrepreneur (Table 4). Such findings go some way towards better understanding if entrepreneurship can be taught and EO can be learnt.

The responses reflect a variety of subjective opinions which make for an interesting read, both supporting and rejecting existing literature strands. Here, context is not as obvious, although one could argue that the Swedes concretely agree that logically anyone can become an entrepreneur - at the superficial level of interpretation at least. Deeper analysis suggests that this question requires further investigation as the role of teaching entrepreneurship seems contested by the entrepreneurs themselves, which would indicate the non-necessity of entrepreneurship education from the practising entrepreneurs' perspective.

The indifference towards official education or training was signalled by interviewees from all three contexts, alongside the notion by some, that it could do no harm. For example, Company A (Finland) notes 'you have to have some kind of idea what it takes to become an entrepreneur, but you don't have to go to a particular school or have four years of training'. Company D of Portugal furthers 'there are examples of very successful people who have created great empires from scratch, basically with good judgment and common sense. So, I don't think it's something necessary'. And, Company G of Sweden emphasises that 'the most important thing is personality, i.e. if you have the drive and other personal traits necessary to start and build all the components of a new company'. This goes some way towards validating the importance of individual traits and EO as intrinsic.

The responses not only reflect the dynamisms and debates inherent within the academic field but too the subjectivity of the very raison d'etre - the essence - of entrepreneurship and the entrepreneurial mind-set. Thus, contemporary research regarding the necessity of entrepreneurship education remains perplexed against the backdrop of both academic and entrepreneurial debate. Further, as the responses express similitude between the three nations, cultural background therefore does not determine entrepreneurial success by creating specific EO characteristics as some studies would infer (e.g. Hofstede 1984; House et al. 2004), at least not through entrepreneurial training at least. This champions the idea that entrepreneurship tendencies borne from within and not the product of culturally specific environments. That is, EO is primarily the result of intrinsic characteristics rather than extrinsic features. Thus, one can only infer that localised factors influence understandings of international entrepreneurship and that instead, entrepreneurial tendencies are primarily based on personality traits. However, the extrinsic indeed creates opportunities through developing core competences, such as language skills through education, as resources to offer international success. Essentially, these responses suggest that language education is essential for the internationalisation process as opposed to official entrepreneurial training programmes. In this sense, the 'entrepreneurship as learnt' paradox remains open to debate. 
Table 4 Entrepreneurship as learnt

Company and Can anyone become an entrepreneur?

Outcome context

\begin{tabular}{|c|c|}
\hline $\begin{array}{l}\text { Company A, } \\
\text { Finland }\end{array}$ & $\begin{array}{l}\text { Well not everybody, but of course you can be an entrepreneur if you are part of a } \\
\text { team. It depends really. }\end{array}$ \\
\hline $\begin{array}{l}\text { Company B, } \\
\text { Finland }\end{array}$ & $\begin{array}{l}\text { In theory yes but not in practice. Being an entrepreneur requires, for example, } \\
\text { willingness to take risks, excellent people skills, and ability to identify and } \\
\text { understand market problems. }\end{array}$ \\
\hline $\begin{array}{l}\text { Company C, } \\
\text { Finland }\end{array}$ & $\begin{array}{l}\text { No, only the ones who have the right mindset. Those people who are willing to } \\
\text { work really really hard... are persistent... believe in themselves... are } \\
\text { orientated to growth thinking and are positive. They also like challenges, they } \\
\text { see challenges as opportunities. They are willing to learn all the time. They are } \\
\text { not afraid to take risks. }\end{array}$ \\
\hline $\begin{array}{l}\text { Company D, } \\
\text { Portugal }\end{array}$ & $\begin{array}{l}\text { It's a good question. I think there are personal characteristics that are necessary to } \\
\text { be an entrepreneur. I think there are many characteristics that can be } \\
\text { developed, but also there are others that are inborn. It has to do with the way } \\
\text { the people are. And I think there are many personality traits of people which } \\
\text { are genetic, born with them. In this way, I think there are people with more } \\
\text { proficiency than others. However, I think there are features that can be } \\
\text { developed, for people that are not born with that profile, but still can make } \\
\text { good entrepreneurs. And, when I say entrepreneur, I'm talking not just about } \\
\text { managers or people who set up a company, etc. Entrepreneur, for me, is more } \\
\text { than that: it is to be able to create things, solve problems-it can be within a } \\
\text { public institution, it may be in your home, it can be found in many forms. }\end{array}$ \\
\hline
\end{tabular}

Company E, I don't think so... you have to take risks... to be very focused, you can't be Portugal mainstream and have good skills. Some people haven't got those characteristics.

Company F, Yes, I believe so. If you really want to have your own business you will work for Portugal

Company G, Sweden

Company H, Sweden it. If you have that desire, you will manage everything to achieve your goals.

I think I'm going to have to say no, I don't think everyone has what it takes. No

I would say yes today, but I have been more definite before that anyone can Yes become an entrepreneur and then becoming less and less sure. But as of today I say yes.

Company I, Good question, I think yes, absolutely I don't think everybody wants to, or that Yes Sweden everybody should ... to do something you need to be passionate about it. If I wanted to be a singer-songwriter I could probably do that if I practiced a lot. You need to really practice a lot to do that. It is the same with entrepreneurship, If you are going to start a company you are going to be working quite a lot of hours, I mean, really long hours, you have to be really sure about what you are doing. You better love what you are doing because that helps you to be good at doing it, but I think that goes for everything in life.

\section{Concluding discussion}

Evidently, language ability is seen as a source of competitive advantage from the entrepreneurs' perspective. The entrepreneurs agree on the acuteness of language for successful market entry strategies in the form of legitimacy and opportunity, as well as its potential for new foreign market selection. Based on the responses, language and communication are proposed as 'services' in order to respond to clients' needs in a 
timely, efficient manner. Such skills are considered vital in order to boost legitimacy, trust and awareness, as well as to mutually reinforce respect at the business-customer interface. Nevertheless, geographical differences are evident and there appears a spectrum from organisational rapport-building to legitimacy as communication strategies. This suggests that language is viewed strategically as a tool to build organisational rapport over time and space to maximise profit in its broader sense beyond economic considerations, giving rise to legitimate firms in the eyes of the 'other'. Thus, language ability can be considered a resource borne from the institutional environment which positively affects start-up success. Although, a continuum from fundamentally communicative strategies towards the more pragmatic appears to exist.

The nuances drawn out through exploring language and education, as the measureable components of culture, indicate that broader institutional forces are at play. Indeed, language ability is founded upon domestic educational systems and has the potential to reduce the liability of foreignness. Nevertheless, the perceived role of formal education for the entrepreneurs is weak, leading us to suppose that perhaps the informal 'educational' sources per se, such as building cultural awareness and organisational rapport through the medium of language, are more important. To this end, the findings primarily relate to normative and cultural-cognitive elements of Scott's (2014) institutionalism, over and above the regulative forces assumed by formal educational. In this sense, the regulative pillar becomes obscured throughout the responses, often taken as normative or cultural-cognitive dimensions.

Ultimately, this study has aimed to increase understandings of the complexity within the European entrepreneurial environment from the perspective of the entrepreneur by exploring: (a) the impact language ability has on start-up expansion; (b) international relations as based on language ability as a tool for cross-cultural communication; and (c) the role of educational context in the production of competent entrepreneurs in three discrete linguistic environments, Finland, Portugal and Sweden. Building on combined actor-context perspectives, it concludes that language ability through education appears to positively affect start-up success. It emphasises the positive role that this resource can have for start-up expansion, as well as being a tool for cross-cultural communication that promotes rapport, trust and legitimacy across geographical borders. Hence, the research bridges institutional and resource-based views. Nevertheless, the 'entrepreneurship as learnt' paradox, which proposes that entrepreneurial education is prerequisite to (international) success and entrepreneurial orientation, remains unclear. As such, the findings point more towards entrepreneurship being a culture in itself, superseding national borders or cultural blocs and therefore rejecting the notion of cultural clusters.

\section{Contributions}

This study contributes to the international entrepreneurship literature and has both academic and practical implications. Academically, it helps advance understandings of the role of geography and language ability in entrepreneur research under the framing of institutional theory and the potential of discrete formal and informal educational systems affecting international success. This serves to bridge the gap between agent and context-centric perspectives (see Garud Gehman and Giuliani 2014) and resource-based/institutional views (see Meyer et al. 2009; Peng et al. 2009). It also adds to the discussion on the value of entrepreneurship education from 
the perspective of active entrepreneurs. Moreover, these first-hand experiences may prove useful for budding entrepreneurs in that entrepreneurial education may not be prerequisite but that competent language ability can prove fruitful for long-term success. Ultimately, it appears that for successful international relations and customer satisfaction, language ability is the resource for cross-cultural communication. It increases both customer trust and rapport, as well as organisational reputation to varying degrees in all three context. Thus, language ability most likely has implications for start-up success and subsequent profit maximisation. But, beyond that, an awareness of cultural rules and traits is also considered paramount.

\section{Limitations and future research}

Indeed, one could argue that studying start-up companies from discrete environments serves little to highlight the postmodernist world by attempting to reduce complexity per se to discrete entities at the locale, bounded by artificial geographies. Nevertheless, this argument is herein void as the aims were to explore if culture and language are considered to play vital roles on (the perception of) success from the company's perspective and if this indeed varies over space. Notwithstanding, given that this study is based on a small sample, it cannot be generalised. Rather, it can serve as a baseline or catalyst for future indepth, longitudinal case studies, offering a valid base-assessment of language ability and entrepreneurial education from the entrepreneurs' perspective.

Second, with regard to context, the undertones of Swedish indifference as well as the dynamics of environmental interactions and entrepreneurial personality traits require further attention. That is, research is needed that conducts deeper empirical contextual and analytical examination to expound on the present discussion by providing a richer description of the contextual nuances. To this end, the geographical mapping of entrepreneurship tendencies can be extended from the macro-level country analysis to the micro-level regional analysis (see Tödtling and Wanzenböck 2003).

Third, another point of interest would be to investigate IT language in B2B markets as moderating the reliance on conventional linguistic forms. ${ }^{5}$ Here, it is assumed that such communicative technologies in themselves offer a 'global' language based on coding that does not rely on traditional lexical forms.

Finally, the interaction between institutional theory and the resource-based view can be developed in entrepreneurship research. Specifically, regulatory aspects may be developed whereby entrepreneurial tendencies are the result of context-bound reward and compensation fiscal structures which promote-or hinder-innovation and growth.

Acknowledgements The authors would especially like to thank the constructive comments of Charlotta Edlund, Mälardalen University, Sweden, Alexandra Leandro, Instituto Politécnico de Coimbra, Portugal, and Elina Halonen, Mikkeli University of Applied Sciences, Finland. We would also like to thank the insightful experience received at Euroweek 2016, hosted by Haute Ecole Léonard de Vinci, Brussels, which is championed as the inspiration for this paper. However, we are particularly grateful to the comments of two anonymous reviewers as well as Dr. Hamid Etemad on earlier versions of this paper. The authors had varying roles in the production of this paper. The first author was responsible for data design, collection and initial analysis and solely responsible for secondary analysis and write-up from 2016 to 2018. The other authors were responsible for data design, collection and initial analysis in 2016.

\footnotetext{
${ }^{5}$ As rightfully highlighted by an anonymous reviewer.
} 


\section{Compliance with ethical standards}

Conflict of interest The authors declare that they have no conflict of interest to note.

\section{Appendix A}

Table 5. Themes of rapport-building, trust and relationships from the interviews

Themes/concepts

Company A. When we go to Korea we [...] say something with their native language that makes a huge impact. And we want to take this as an advantage, and learn their business culture [...] In that way you can show that you are really interested in their company and we want to understand their needs. We want to know everything, how to do business there $[\ldots]$ how they work there, and how they behave in the meetings. Because there is more cultural hierarchy inside the company. There are very strict rules and things that they do differently.

Company A. The good thing about cultural differences: that people have been surprised that we keep our promises like deadlines. Sometimes we need to filter compliments for example from US, because some people want to steal your ideas in the meetings. People in US are more into giving compliments, it's more like a routine, but in Finland, if you give a compliments it mean that you have done something really well.

Company A. The main thing in the international business is that you must make sure that your message has gone through and you can repeat and ask if we are on the same page with the customer etc. and both [understand each other].

Company A. It's not necessary [to modify your behaviour] when working abroad. I think that everybody can be themselves. [...] I think that it is cultural richness. But of course you have to understand people to whom you are talking with.

Company B. The local language always matters, so when you go to the Russia it is good to know Russian and if you go to China, knowing Chinese will help you for sure.

Company B. We wondered if we would succeed on the other side by the Earth in a completely different culture of people [and] decided to try but unfortunately it didn't work.

Company B. I have noticed that when you write text it can be read in many different ways so it is good to sometimes, and quite often, to speak via Skype or
Finland

Caution, communication clarity, (celebrated) cultural difference, (bilateral) cultural education, cultural richness, cultural tolerance, team spirit, textual discourse 
Table 5. (continued)

Themes/concepts

phone and, if possible, [...] meet and do some things together. You can do many things from the distance but it is good for everyone to meet because of team spirit and communication.

Company C. Until now [we have not had to modify our behaviour as] we have only dealt with people coming from Western cultures. Therefore, this has not been an issue.

Company C. As a Finn, I believe that it's important to use the local language. At least in Finland people feel a bit shy if they have to speak another language even if it's English.

Company C. [We have] users from many cultures so of course we need to understand this. We need to take this into consideration when communicating with them, when promoting.

Company $\mathrm{C}$. There should be training in some form at least and it would be good if those employees read some books about different cultures as we have done, and they would have some background about people from other cultures.

Company C. We also want to educate them to understand Finnish culture, and how we communicate here in Finland.

Company C. I think you should understand your own culture and then you should study about those cultures that you are dealing with in the business life, but the thing is that when we operate in Finland things should be done in the Finnish way, and if you go to Japan, then things are done in the Japanese way.

Company C. I am a bit more careful and more alert with foreign people if I don't know them well.

Company D. Without communication you can't develop and grow and, often, important messages are lost, which can have very negative repercussions.

Company D. When Portuguese people speak Spanish, sometimes we use terms inappropriately, and the receiver can misunderstand the message or only half the message, so it is common and can happen. What helps a lot to solve this problem is asking for feedback (if they understood the message). In everyday life, we don't usually have these kind of problems of language and cultural differences.

Company D. There's no sense in being too extremist. We always try to understand what the customer needs.

Company D. It is essential to find this balance, find a way to please everyone and, above all, to make the company grow.
Portugal

Communication necessity, consensus, cultural adaptation, (bilateral) cultural education, cultural integration, cultural (mis)understanding, cultural tolerance, difference of perspectives, empathy, interaction, local responsiveness, management as a role model, open-mindedness 
Table 5. (continued)

Themes/concepts

Company D. I think [cultural understanding] is happening quite in a natural way.

Company D. I think it's all about people's soft skills. To have the capacity of being well informed, don't have this kind of prejudice, the manager must be careful to set a good example and never discriminate against anyone.

Company D. We try to approach them culturally, in all aspects. Since trying to focus our discussion on matters that are important to them, talk about their country, about their culture, always in a respectful way, of course - never missing the respect - also trying to explain our culture. Promoting our country and show the good things of our country and culture. In the same way that we try to see the good points and praise their culture. To try to create bridges and empathy, to make all of us feel good and to create ties and sustained business.

Company D. A key thing to [...] all this is people becoming open minded by travelling and getting out of [their]comfort zones and meeting other cultures, even outside the context of work. So people can more easily achieve this cultural understanding and tolerance which are essential. Both language and cultural skills, can be reached more easily, by travelling. People can learn more in one day on a trip, than during a month, in a library.

Company E. I've never had serious problems of miscommunication occurred due to language difference. We just need to take care and be sure everything is ok and all was well understood. You must choose a language to conduct a business that is understood by the two sides. You are locally responsive when you adapt yourself to the local reality and culture. That's what we try in Company $\mathrm{E}$, we are trying to attend the interests of our customers.

Company E. We are all super open-minded, and we try everyday adapt to new realities and other cultures. We work every single day with people all over the world, so tolerance and cultural understanding are embedded in our employees.

Company E. You need to adapt, be flexible and be honest. For example, if you're in USA, you follow USA culture, if you're working with Canadian people, you should be flexible and have knowledge about their culture to know how to act.

Company E. Sometimes people have different perspectives but we always try to reach a consensus.

Company E. With Brazilian people [we modify our behaviour] we are super relaxed because they are 
Table 5. (continued)

Themes/concepts

always in good mood. With USA people we can't have the same behaviour because [they] are very focused, and working, [and] that's no time to have fun.

Company F. [It] is an advantage have someone that talks the local language.

Company F. You must choose a language to conduct a business that is understood by the two parts of the business. You are locally responsive when you adapt yourself to the local reality and culture, when you are flexible to understand other points of view.

Company F. We act in different markets, so they have to have the capacity to adapt themselves to other cultures.

Company F. You need to adapt you, have knowledge about the other culture and above all respect it.

Company F. You just need to know the others and get the better way to involve yourself with them.

Company F. Every situation is unique, and for each you have a different way to interact.

Company F. If you know about a culture and if you're a flexible person that respects that culture you will be able to insert you in that "habitat"-for example to show your product. If you're a conscious person, everything will be ok.

Company G. It is important for our Swedish customers to know that when they extend $[\ldots]$ we are extending with them.

Company G. Our main plan is to have the main site in English but the own landing site and the basic information about each county in their own language $[\ldots]$ for support.

Company G. We want to stay close to the customer, we want our employees to be happy $[\ldots]$ and $[\ldots]$ engaged in their work.

Company G. We might seem slightly more distant I suppose with this strategy [of being locally responsive]. More close to the Swedish market. But then I don't know if that's a good or bad thing. I think the most important thing is that we have [a knowledge level] similar [...] to the one that we are communicating with.

Company G. In a lot of international situations people have a very different view with what is an acceptable business model for example.

Company $\mathrm{H}$. When you expand internationally you really have to be very skilled, otherwise you are going to run into credibility problems $[. .$.$] call it$ problems with confusion if you are not good enough.
Sweden

Closeness to customer, consensus, contextual responsiveness via support services, credibility, cultural difference, cultural understanding, empathy, equality, extend with customers to new markets, foreign/local representations, international culture, respect, skills necessity 
Table 5. (continued)

\section{Themes/concepts}

Company H. [Regarding communicating abroad] some kind of local representation [...]. It doesn't have to be people physically located in those areas, but some kind of representation. We are going to need to adapt $[\ldots]$ because in many countries English is not as widely used.

Company H. There is an international culture, there is also culture stemming from what type of business the founders may have been in before $[\ldots]$ the founders, where they come from, nationally and previous work-experience will have influence on where the start-up ends.

Company H. The Swedish consensus mentality [...] is something $[\ldots]$ very prominent in our company culture in the sense that we care a lot about that everybody gets a say, to speak up and say what they want to do, what their opinion is etc., and then we shape our way forward together. It is not the same thing as taking the consensus mentally to its extreme.

Company H. You simply have to be very respectful and be very eager to understand I would say, where other people come from. So, listen, learn and understand, and from that you can go on and start to understand them.

Company H. You have to be much more responsive to how people act, and what they say and do and you have to be more careful.

Company H. You have to be careful that you don't just do things as you would at home and assume that people will do or say as they do, it is more about this listening thing.

Company I. I think sometimes time we have less empathy for each other [than] when you are speaking your native language.

Company I. In Brazil, the business culture is very different, you have to be with people, you have to be closer to somebody before you can do business with them, in comparison to Sweden or the UK where you can be much more straightforward with what you can say and what you think about things $[\ldots]$ in South America it is more about building relationships and so on.

Company I. I think culture is everything. 
Open Access This article is distributed under the terms of the Creative Commons Attribution 4.0 International License (http://creativecommons.org/licenses/by/4.0/), which permits unrestricted use, distribution, and reproduction in any medium, provided you give appropriate credit to the original author(s) and the source, provide a link to the Creative Commons license, and indicate if changes were made.

\section{References}

Andersen H, Rasmussen E (2004) The role of language skills in corporate communication. Corp Commun Int J 9(3):231-242

Autio E, Keeley RH, Klofsten M, Ulfstedt T (1997) Entrepreneurial intent among students: testing an intent model in Asia, Scandinavia and USA. In: Reynolds PD (ed) Frontiers of Entrepreneurship Research, Proceedings of the seventeenth annual Entrepreneurship Research Conference. Babson College, Wellesley Mass, pp 133-147

Barner-Rasmussen W, Ehrnrooth M, Koveshnikov A, Mäkelä K (2014) Cultural and language skills as resources for boundary spanning within the MNC. J Int Bus Stud 45(7):886-905

Barney J (1991) Firm resources and sustained competitive advantage. J Manag 17:771-792

Bates T (1995) Self-employment entry across industry groups. J Bus Ventur 10:143-156

Bazeley P (2013) Qualitative data analysis: practical strategies. Sage, London

Bell J, Callaghan I, Demick D, Scharf F (2004) Internationalising entrepreneurship education. J Int Entrep 2: 109-124

Bergmann H (2011) Entrepreneurship disparities within Switzerland - do tax and language differences play a role? Entrep Reg Dev 23(7-8):523-548

Bird BJ (1988) Implementing entrepreneurial ideas: the case for intention. Acad Manag Rev 13(3):442-453

Bird BJ (1992) The operation of intentions in time: the emergence of the new venture. Enterp Theory Pract 17(1):11-21

Bonaventura L, Caserta M (2012) The social dimension of entrepreneurship: the role of regional social effects. Entrep Res J 2(3):2157-5665. https://doi.org/10.1515/2157-5665.1079.

Bowen D, Hisrich R (1986) The female entrepreneur: a career development perspective. Acad Manag J 11(2): 393-406

Boyd NG, Vozikis GS (1994) The influence of self-efficacy on the development of entrepreneurial intentions and actions. Entrep Theory Pract 18:63-77

Brannen MY, Piekkari R, Tietze S (2014) The multifaceted role of language in international business: unpacking the forms, functions and features of a critical challenge to MNC theory and performance. $\mathrm{J}$ Int Bus Stud 45:495-507

Brouthers KD, Brouthers LE, Werner S (2008) Resource-based advantages in an international context. J Manag 34(2):189-217

Brush CG, Manolova TS, Edelman LF (2008) Separated by a common language? Entrepreneurship research across the Atlantic. Entrepreneurship Theory and Practice 32(2):249-266

Bruton GD, Ahlstrom D, Li HL (2010) Institutional theory and entrepreneurship: where are we now and where do we need to move in the future? Entrep Theory Pract 34(3):421-440

Bryman A, Bell E (2015) Business research methods, 4th edn. Oxford University Press, Oxford (UK)

Chiang P, Yang C (2014) Culture as an engine for start-up networks in a cultural and creative product-based small service. In PICMET '14: Infrastructure and Service Integration: IEEETrans.

Chuang M, Chen C, Lin MJ (2016) The impact of social capital on competitive advantage: the mediating effects of collective learning and absorptive capacity. Manag Decis 54(6):1443-1463

Covin JG, Miller D (2014) International entrepreneurial orientation: conceptual considerations, research themes, measurement issues, and future research directions. Entrep Theory Pract 38(1):11-44

Crick D (2009) The internationalisation of born global and international new venture SMEs. Int Mark Rev 26(4/5):453-476

da Rocha A, Simões VC, de Mello RC, Carneiro J (2017) From global start-ups to the borderless firm: why and how to build a worldwide value system. J Int Entrep (online) doi: https://doi.org/10.1007/s10843017-0200-9, 15, 121, 144.

Davidsson P, Honig B (2003) The role of social and human capital among nascent entrepreneurs. J Bus Ventur 18(3):301-331 
De Noni I, Apa R (2015) The moderating effect of exploitative and exploratory learning on internationalisation-performance relationship in SMEs. J Int Entrep 13:96-117. https://doi.org/10.1007 /s10843-015-0148-6

Dennehy E (2015) Hofstede and learning in higher level education: an empirical study. Int J Manag Educ 9(3): 323-339. https://doi.org/10.1504/IJMIE.2015.070125

Díez-Martín F, Blanco-González A, Prado-Román C (2016) Explaining nation-wide differences in entrepreneurial activity: a legitimacy perspective. Int Entrep Manag J 12:1079-1102. https://doi.org/10.1007 /s11365-015-0381-4

Dodd SD, Patra E (2002) National differences in entrepreneurial networking. Entrep Reg Dev 14(2):117-134

Donckels R (1991) Education and entrepreneurship experience from secondary and university education in Belgium. J Small Bus Enterp 9(1):35-42

Dorfman W, Javidan M, Hanges X (2012) GLOBE: a twenty year journey into the intriguing world of culture and leadership. J World Bus 47:504-518. https://doi.org/10.1016/j.jwb.2012.01.004

Drakopoulou Dodd S, Hynes BC (2012) The impact of regional entrepreneurial contexts upon enterprise education. J Entrepr Reg Dev 24(9-10):741-766. https://doi.org/10.1080/08985626.2011.566376.

Engelen A, Heinemann F, Brettel M (2009) Cross-cultural entrepreneurship research: current status and framework for future studies. J Int Entrep 7:163-189. https://doi.org/10.1007/s10843-008-0035-5

Erikson T (2001) Revisiting Shapero: a taxonomy of entrepreneurial typologies. N Engl J Entrep 4(1):9-15

Ernst and Young (2015) Megatrends 2015-making sense of a world in motion. Ernst and Young Global Limited. http://www.ey.com/Publication/vwLUAssets/ey-megatrends-report-2015/\$FILE/ey-megatrendsreport-2015.pdf Accessed between November 2015-April 2016

Etemad H (2015) The promise of a potential theoretical framework in international entrepreneurship: an entrepreneurial orientation-performance relation in internationalized context. J Int Entrep 13:89-95. https://doi.org/10.1007/s10843-015-0157-5

Fane L (2012) Languages and entrepreneurship - a guide for students. The Higher Education Academy UK. http:/www.ucml.ac.uk/sites/default/files/shapingthefuture/101/Languages_and_entrepreneurship.pdf Accessed 6 February 2016

Farny S, Hedeboe Frederiksen S, Hannibal M, Jones S (2016) A CULTure of entrepreneurship education. J Entrep Reg Dev 28:514-535. https://doi.org/10.1080/08985626.2016.1221228

Fayolle A (2013) Personal views on the future of entrepreneurship education. J Entrep Reg Dev 5(7-8):692701. https://doi.org/10.1080/08985626.2013.821318.

Fligstein N (1997) Social skill and institutional theory. Am Behav Sci 40(4):397-405

Frank H, Lueger M, Korunka C (2007) The significance of personality in business start-up intentions, start-up realization and business success. J Entrep Reg Dev 19(3):227-251. https://doi.org/10.1080 /08985620701218387.

Fredriksson R, Barner-Rasmussen W, Piekkari R (2006) The multinational corporation as a multilingual organization: the notion of a common corporate language. Corp Commun Int J 11(4):406-423

Garud R, Gehman J, Giuliani AP (2014) Contextualizing entrepreneurial innovation: a narrative perspective. Res Policy 43(7):1177-1188

Ghauri PN, Cateora P (2014) International marketing, 4th edn. McGraw Hill, Maidenhead

Gorman G, Hanlon D, King W (1997) Some research perspectives on entrepreneurship education, enterprise education and education for small business management: a ten-year literature review. Int Small Bus J 15(3):56-78

Gupta V, Hanges PJ, Dorfman P (2002) Cultural clusters: methodology and findings. J World Bus 37(1):11-15

Hartley J (2004) Case study research. In: Catherine C, Symon G (eds) Essential guide to qualitative methods in organizational research. Sage, London, pp 323-333

Harzing A, Pudelko M (2013) Language competencies, policies and practices in multinational corporations: a comprehensive review and comparison of Anglophone, Asian, Continental European and Nordic MNCs. J World Bus 48:87-97

Hechavarría DM (2015) The impact of culture on national prevalence rates of social and commercial entrepreneurship. Int Entrep Manag J 12:1025-1052. https://doi.org/10.1007/s11365-015-0376-1

Hofstede G (1984) Cultural dimensions in management and planning. Asia Pac J Manag 1(2):81-99

Holt R (2008) Using activity theory to understand entrepreneurial opportunity. Mind Cult Act 15(1):52-70

Hoppe MJ (2007) Culture and leader effectiveness: the GLOBE study. http://wwwinspireimagineinnovatecom/pdf/globesummary-by-michael-h-hoppepdf Accessed 7 February 2016

House RJ, Hanges PJ, Javidan M, Dorfman PW, Gupta V (2004) Culture, leadership, and organizations: the GLOBE Study of 62 Societies. In Hoppe, M.H. (2007) Culture and leader effectiveness: the GLOBE study. London: Sage. 
Hunt SD (2002) Resource advantage theory and Austrian economics: toward an Austrian theory of competition? http://citeseerxistpsuedu/viewdoc/download?doi=10111986946andrep=rep 1 andtype=pdf Accessed 2 February 2016

Hurmerinta L, Nummela N, Paavilainen-Mäntymäki E (2015) Opening and closing doors: the role of language in international opportunity recognition and exploitation. Int Bus Rev 24(6):1082-1094

Hymer SH (1976) International operations of national firms: a study of direct investment. MIT Press, Cambridge, MA

Hytti U, O'Gorman C (2004) What is "enterprise education"? An analysis of the objectives and methods of enterprise education programmes in four European countries. Educ Train 46(1):11-23. https://doi. org/10.1108/00400910410518188

Isenberg D (2008) The global entrepreneur. Harvard Business Review Online https://hbrorg/2008/12/theglobal-entrepreneur Accessed 30 January 2016

Jacobowitz A, Wilder DC (1982) Characteristics of entrepreneurs: implications for vocational guidance. The Vocational Guidance Quarterly 30(3):252-257

Johanson J, Vahlne JE (1990) The mechanism of internationalization. Int Mark Rev 7(4):11-24

Johannisson B (2016) Limits to and prospects of entrepreneurship education in the academic context. J Entrep Reg Dev 28(5-6):403-423. https://doi.org/10.1080/08985626.2016.1177982.

Klyver K, Foley D (2012) Networking and culture in entrepreneurship. J Entrepr RegDev 24(7-8):561-588. https://oi.org/10.1080/08985626.2012.710257.

Knight GA, Liesch PW (2016) Internationalization: from incremental to born global. J World Bus 51:93-102

Krueger N, Brazeal DV (1994) Entrepreneurial potential and potential entrepreneurs. Entrepr Theory Pract 18(3):91-104

Kulkarni M (2015) Language-based diversity and faultlines in organizations. J Organ Behav 36:128-146

Laperrière A, Spence M (2015) Enacting international opportunities: the role of organizational learning in knowledge-intensive business services. J Int Entrep 13(3):212-241

Larson A, Starr JA (1993) A network model for organization formation. Entrep Theory Pract 17(2):5-15

Lawrence T (2015) Global leadership communication: a strategic proposal. Creighton J Interdisciplinary Leadersh 1(1):51-59

Leslie D, Russell H (2006) The importance of foreign language skills in the tourism sector: a comparative study of student perceptions in the UK and continental Europe. Tour Manag 27:1397-1407

Lounsbury M, Glynn MA (2001) Cultural entrepreneurship: stories, legitimacy, and the acquisition of resources. Strateg Manag J 22(6-7):545-564

Low MB, Abrahamson E (1997) Movements, bandwagons, and clones: industry evolution and the entrepreneurial process. J Bus Ventur 12(6):435-457

Lumpkin GT, Dess GG (1996) Clarifying the entrepreneurial orientation construct and linking it to performance. Acad Manag Rev 21(1):135-172

MacLean D (2006) Transnational corporations and the strategic management of language in a complex multilingual business environment. Manag Decis 44(10):1377-1390. https://doi.org/10.1108 /00251740610715704.

Mainela T, Puhakka V, Servais P (2015) Boundary crossing for international opportunities. J Int Entrep 13: 173-185. https://doi.org/10.1007/s10843-015-0158-4

Marschan-Piekkari R, Welch D, Welch L (1999) In the shadow: the impact of language on structure, power and communication in the multinational. Int Bus Rev 8(4):421-440

McAuley A (1999) Entrepreneurial instant exporters in the Scottish arts and crafts sector. J Int Mark 7(4):6782

McDougall PP, Shane S, Oviatt BM (1994) Explaining the formation of international new ventures: the limits of theories from international business research. J Bus Ventur 9:469-487

McKeever E, Anderson A, Jack S (2014) Entrepreneurship and mutuality: social capital in processes and practices. J Entrep Reg Dev 26(5-6):453-477. https://doi.org/10.1080/08985626.2014.939536.

Meyer KE, Estrin S, Bhaumik SK, Peng MW (2009) Institutions, resources, and entry strategies in emerging economies. Strateg Manag J 30(1):61-80

Miller D (2011) Miller (1983) revisited: a reflection on EO research and some suggestions for the future. Entrep Theory Pract 35(5):873-894

North DC (1991) Institutions. J Econ Perspect 5(1):97-112

Okrent A (2014) Feast your eyes on this beautiful linguistic family tree. Mentalfloss. Accessed 2 February $2016 \mathrm{http}: / /$ mentalfloss.com/article/59665/feast-your-eyes-beautiful-linguistic-family-tree

Peng MW, Sun SL, Pinkham B, Chen H (2009) The institution-based view as a third leg for a strategy tripod. Acad Manag Perspect 23(3):63-81 
Pinho JC (2017) Institutional theory and global entrepreneurship: exploring differences between factor-versus innovation-driven countries. J Int Entrep 15:56-84

Pollack JM, Rutherford MW, Seers A, Coy AE, Hanson S (2016) Exploring entrepreneurs' social network ties: quantity versus quality. J Bus Venturing Insights 6:28-35. https://doi.org/10.1016/j.jbvi.2016.09.001

Qian G, Li L, Rugman AM (2013) Liability of country foreignness and liability of regional foreignness: their effects on geographic diversification and firm performance. J Int Bus Stud 44(6):635-647

Rae D (2012) Action learning in new creative ventures. Int J Entrep Behav Res 18(5):603-623

Roy A, Sekhar C, Vyas V (2016) Barriers to internationalization: a study of small and medium enterprises in India. J Int Entrep 14:513-538. https://doi.org/10.1007/s10843-016-0187-7

Scott RW (2014) Institutions and organizations, 4th edn. Sage, Thousand Oaks, CA

Segal G, Borgia D, Schoenfeld J (2005) The motivation to become an entrepreneur. Int J Entrep Behav Res 11(1):42-57. https://doi.org/10.1108/13552550510580834

Strauss AL (1987) Qualitative analysis for social scientists. Cambridge University Press, Cambridge

Suchman MC (1995) Managing legitimacy: strategic and institutional approaches. Acad Manag Rev 20(3): 571-610

Swift JS, Wallace J (2011) Using English as the common corporate language in a German multinational. J Eur Ind Train 35(9):892-913. https://doi.org/10.1108/03090591111185574

Tolbert PS, David RJ, Sine WD (2011) Studying choice and change: the intersection of institutional theory and entrepreneurship research. Organ Sci 22(5):1332-1344

Tödtling F, Wazenböck H (2003) Regional differences in structural characteristics of start-ups. J Entrep Reg Dev 15(4):351-370. https://doi.org/10.1080/0898562032000058923.

Trinder R (2013) Business students' beliefs about language learning in a university context. Engl Specif Purp 32:1-11. https://doi.org/10.1016/j.esp.2012.06.003.

Urban B (2006) Entrepreneurship education and entrepreneurial intentions: a prospect for higher education? J Entrep Reg Dev 10(1):85-103. https://doi.org/10.1080/16823200609487131

Welsh DHB, Tullar WL, Nemati H (2016) Entrepreneurship education: process, method or both? J Innov Knowl 1:125-132. https://doi.org/10.1016/j.jik.2016.01.005

Yin RK (2012) Applications of case study research, 4th edn. Sage, London

Überbacher F, Jacobs CD, Cornelissen JP (2015) How entrepreneurs become skilled cultural operators. Organ Stud 36(7):925-951. https://doi.org/10.1177/0170840615575190

Zaheer S (1995) Overcoming the liability of foreignness. Acad Manag J 38(2):341-363

Zaheer S, Mosakowski E (1997) The dynamics of the liability of foreignness: a global study of survival in financial services. Strateg Manag J 18(6):439-463 